\title{
Lentil - a promising new crop for Finland
}

\author{
Clara Lizarazo and Frederick Stoddard
}

University of Helsinki, Department of Agricultural Sciences.

P.O. Box 27 (Latokartanonkaari 5), FI-00014. Finland.

clara.lizarazotorres@ helsinki.fi, frederick.stoddard@helsinki.fi

\begin{abstract}
Finnish agriculture is based on cereal cultivation and nearly half of the total utilized agricultural area ( 2295 thousand ha) is used for cultivating barley, oat, wheat, and rye. In contrast, less than $1 \%$ is used for cultivating grain legumes, mainly pea and faba bean for feed purposes. As a result, Finland has a major dependence on inorganic fertilizers and imported vegetable protein. The Nordic region has many consumers that need gluten-free products and vegetable protein, so there is a potential demand for locally grown food legumes such as lentil. After a promising preliminary trial in 2009, 13 lentil cultivars were screened in Helsinki in 2010, 12 from the Crop Development Centre, University of Saskatchewan, Canada, and one from the University of Göttingen, Germany. Six of these cultivars were selected and screened again in 2011. The experiment was laid out as a randomized complete block trial with four replicates in all years; data on radiation interception, flowering and maturity were collected during the growing season. Growing degree-days (GDD) were calculated using a $5^{\circ} \mathrm{C}$ base temperature.
\end{abstract}

The 2010 growing season was exceptionally warm and most cultivars performed well, except Sovereign and Sedley that lodged and matured late. There were significant differences in earliness $(\mathrm{P}<0.001)$, the earliest cultivar being Rosetown (902 GDD to maturity), and the latest Sedley (1214 GDD). There were no significant differences in yield ( $\mathrm{P}=0.111)$, the average being $1.49 \mathrm{t} / \mathrm{ha}$. Cultivar Meteor was the highest yielding with 1.86 t/ha but it lodged, whereas cvs Redbow, Redcoat, Rosetown and Milestone yielded 1.5-1.6 t/ha and showed few problems in cultivation, so further experiments have included them. The 2011 growing season was warm enough and allowed all cultivars to mature by the middle of August, most before Kontu faba bean. There were significant differences in earliness $(\mathrm{P}<0.001)$, the earliest cultivar being Rosebud, and the latest Redberry. According to FAOSTAT in 2008, Finland imported only $98 \mathrm{t}$ of lentil, or $18 \mathrm{t} / \mathrm{million}$ inhabitants, whereas other European countries imported considerably more, ranging from $157 \mathrm{t} /$ million in Sweden to $1050 \mathrm{t} / \mathrm{million}$ in Spain. Thus there is clear potential for growth in the market for Finnish-grown lentils.

When the results from the 2011 trials are compiled, we expect to be able to recommend appropriate cultivars to farmers in time for the 2012 growing season.

Key words: earliness, lentil, vegetable protein.

\section{Introduction}

Like most world agricultural systems, Finnish agriculture is based on cereal production, and relies on very simplified crop rotations, with the main products being barley, oat and wheat (Ekroos 2010). In 2009 , of the 2.3 million hectares of arable land, the proportion utilized for pea was $0.2 \%$ and in 2010 it was $0.3 \%$, while the utilized area for faba bean in 2009 was $0.1 \%$ and in 2010 it was $0.4 \%$ (TIKE, 2010). Finnish agriculture needs to increase even more the cultivation of legumes, to help diminish imports of soybean meal and fertilizers, to improve soil characteristics, to improve farmland biodiversity, and to improve quality and yield of crops (Stoddard et al. 2009).

The climatic conditions in Finland's short growing season restrict the range of crops that can be grown, but other northern countries have achieved to include crops other than cereals in their rotations. For example, in Saskatchewan, Canada the cultivation of grain legumes has increased remarkably since 1981, and currently Canada is the top producer of lentil (Lens culinaris Medik.) in the world (Carlyle 2004, FAOSTAT 2011). 
The lentil is one of the most important grain legumes, ranking sixth in terms of production world-wide. Of the production, $70 \%$ is small-seeded lentils with red cotyledons, $25 \%$ green largeseeded and only 5\% brown lentils. In Europe, the main producers of lentils are France and Spain, while the main importers are Spain and Italy (Erskine et al. 2009). According to FAOSTAT in 2008, Finland imported only $98 \mathrm{t}$ of lentil, or $18 \mathrm{t} /$ million inhabitants, whereas other European countries imported considerably more, ranging from $157 \mathrm{t} /$ million in Sweden to $1050 \mathrm{t} / \mathrm{million}$ in Spain. Thus there is clear potential for growth in the market for Finnish-grown lentils.

Lentil is considered, after barley, the second crop for the most challenging agricultural environments (Erskine et al. 2009). The aim of this research is to find early cultivars of spring-sown lentils suitable for Finnish environmental conditions.

\section{Materials and Methods}

Experiments were conducted in Helsinki at the Viikki Experimental Farm. Four cultivars were screened in 2009, 13 in 2010 and of these, 6 were tested again in 2011, chosen according to their performance in flowering, maturity, disease resistance and yield.

Twelve lentil cultivars were obtained from the Crop Development Centre, University of Saskatchewan, Canada, and one from Dr Bernd Horneburg, Georg August University of Göttingen, Germany. The experiment was laid out as a randomized complete block trial with four replicates. Plots were $1.25 \mathrm{~m}$ wide and $6 \mathrm{~m}$ long. Row spacing was $25 \mathrm{~cm}$ in 2009 and $12.5 \mathrm{~cm}$ in the other years and seed spacing was adjusted to provide the growing densities of $120-140 \mathrm{~m}^{-2}$ recommended by the breeders.

Lentil seeds were inoculated with rhizobium before planting, and were sown on 7 May 2009, 13 May 2010 and 10 May 2011. Plant phenology was monitored daily, and dates were recorded when $10 \%, 50 \%$ and $90 \%$ of the plants in a plot reached flowering and maturity. Growing degree-days (GDD) to these points were calculated using a $5^{\circ} \mathrm{C}$ base temperature. A subplot of $0.5 \mathrm{~m}^{2}$ was manually collected from each plot at maturity for quality analysis and yield estimation. Data were analyzed by one and two way analysis of variance using PASW Statistics 18 (SPSS Inc., Chicago, USA).

\section{Results and Discussion}

The three growing seasons in Helsinki had different weather patterns: 2009 was wet and cool, 2010 was very dry and 2011 was warm in the beginning but wet at the end (Figure 1). The maturity date of the cultivars varied significantly across the years, while other parameters did not vary significantly between years.

During the damp growing season of 2009, the lentils did not stop flowering, there were some signs of disease, and pigeons did considerable damage to the plots, but it served to identify Redberry as the least susceptible cultivar to Sclerotinia of the four (cvs. Plato, Viceroy and Robin).

In contrast, the growing season of 2010 was very dry and the majority of cultivars performed well, with the exception of cvs Sovereign and Sedley which lodged and matured late. There were significant differences between cultivars in all the phenological stages: to $10 \%$ flowering and to $50 \%$ flowering ( $\mathrm{P}<0.01)$, to $90 \%$ flowering $(\mathrm{P}<0.05)$, and to $10 \%$ and $90 \%$ maturity $(\mathrm{P}<0.001)$. The earliest cultivar was cv. Rosetown (902 GDD), and the latest cv. Sedley (1215 GDD). There were no significant differences in yield ( $\mathrm{P}>0.05)$, the average being $1.49 \mathrm{t} / \mathrm{ha}$. Cultivar Meteor was the highest yielding with $1.87 \mathrm{t} / \mathrm{ha}$ but it lodged, whereas cvs. Redberry, Redbow, Redcoat, Rosetown and Milestone yielded between 1.5-1.6 t/ha and showed few problems in cultivation, so they were chosen to be screened again in the following season. 

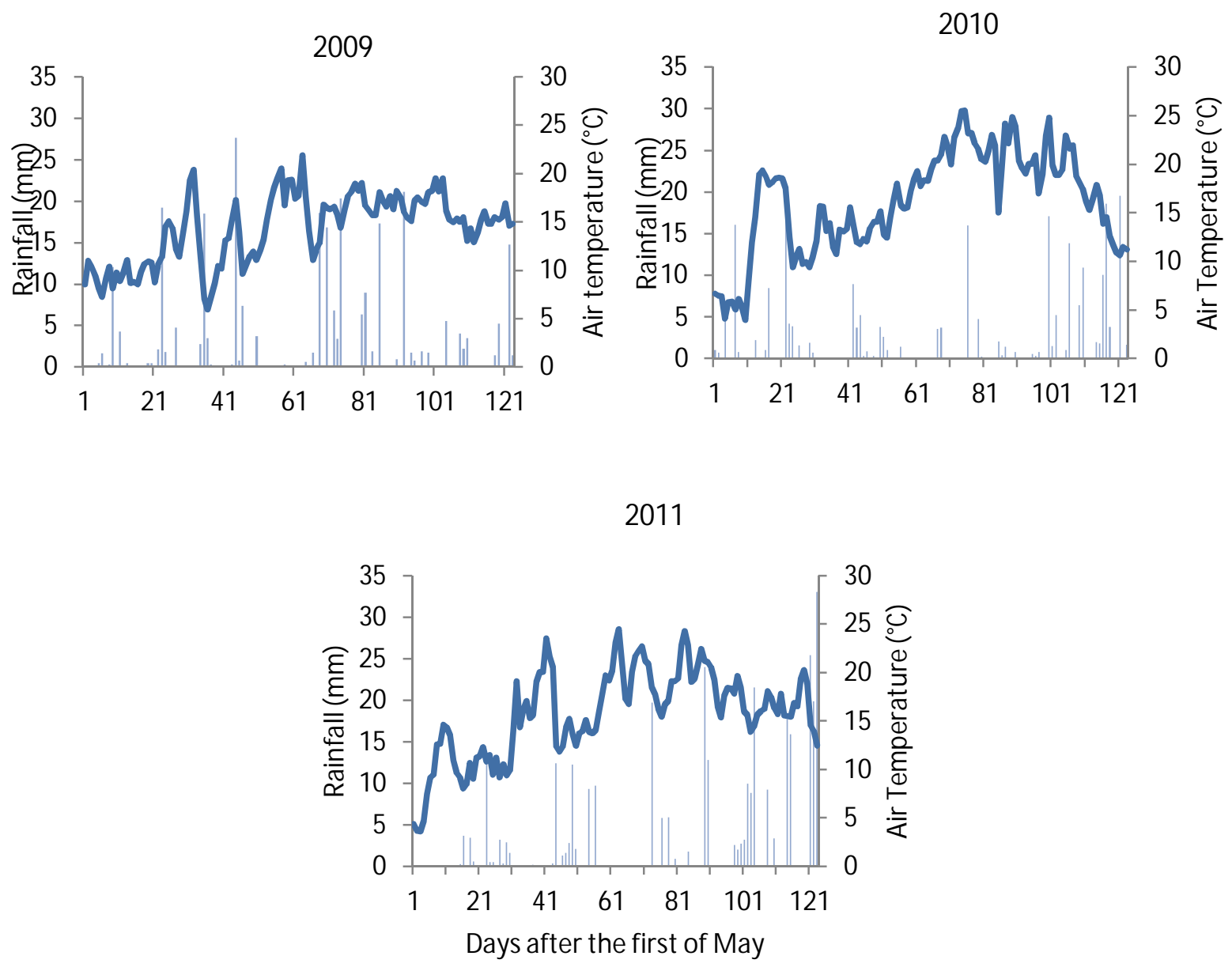

Figure 1. Daily mean air temperature and daily mean accumulated rainfall during the growing seasons (May - August) of 2009-2011 in Helsinki, Finland.

Table 1. Mean growing degree days (GDD) to $90 \%$ maturity, seed yield (t/ha) and protein content $(\mathrm{g} / \mathrm{kg})$ of 13 lentil cultivars screened in Helsinki during 2010 growing season.

\begin{tabular}{lrrr}
\hline Cultivar & GDD to Maturity $90 \%$ & Seed yield (t/ha) & Protein content $(\mathrm{g} / \mathrm{kg})$ \\
\hline Black & 943 & 1.05 & 326 \\
Blaze & 961 & 1.38 & 302 \\
Meteor & 969 & 1.87 & 264 \\
Milestone & 925 & 1.54 & 267 \\
Redberry & 991 & 1.54 & 303 \\
Redbow & 925 & 1.68 & 275 \\
Redcoat & 976 & 1.65 & 290 \\
Robin & 980 & 1.51 & 316 \\
Rosebud & 929 & 1.39 & 275 \\
Rosetown & 902 & 1.58 & 287 \\
Sedley & 1215 & - & - \\
Sovereign & 1137 & 1.41 & 290 \\
Viceroy & 994 & 1.40 & 296 \\
& & & \\
\hline
\end{tabular}


The growing season of 2011 was more variable in both temperature and rainfall than either of the previous years, with August being particularly wet (Figure 1). Nevertheless, the cultivars performed well. There were no significant differences between cultivars in flowering $(\mathrm{P}>0.05)$ but there were significant differences in maturity $(\mathrm{P}<0.05)$. The earliest cultivar was cv. Rosebud (961 GDD), followed by cv. Redbow (979 GDD). All cultivars matured later in 2011 than in 2010, with the difference greatest in cv. Rosetown, which required 127 more GDD.

There were no significant differences in flowering date due to year, but there were significant differences between cultivars $(\mathrm{P}<0.05)$ (Table 2$)$. For maturity there were significant differences due to both years and cultivars $(\mathrm{P}<0.001)$. More importantly there was a significant year $\mathrm{x}$ cultivar interaction for both flowering and maturity, so it is clear that weather conditions have a key impact on the fitness of cultivars (Figure 2).

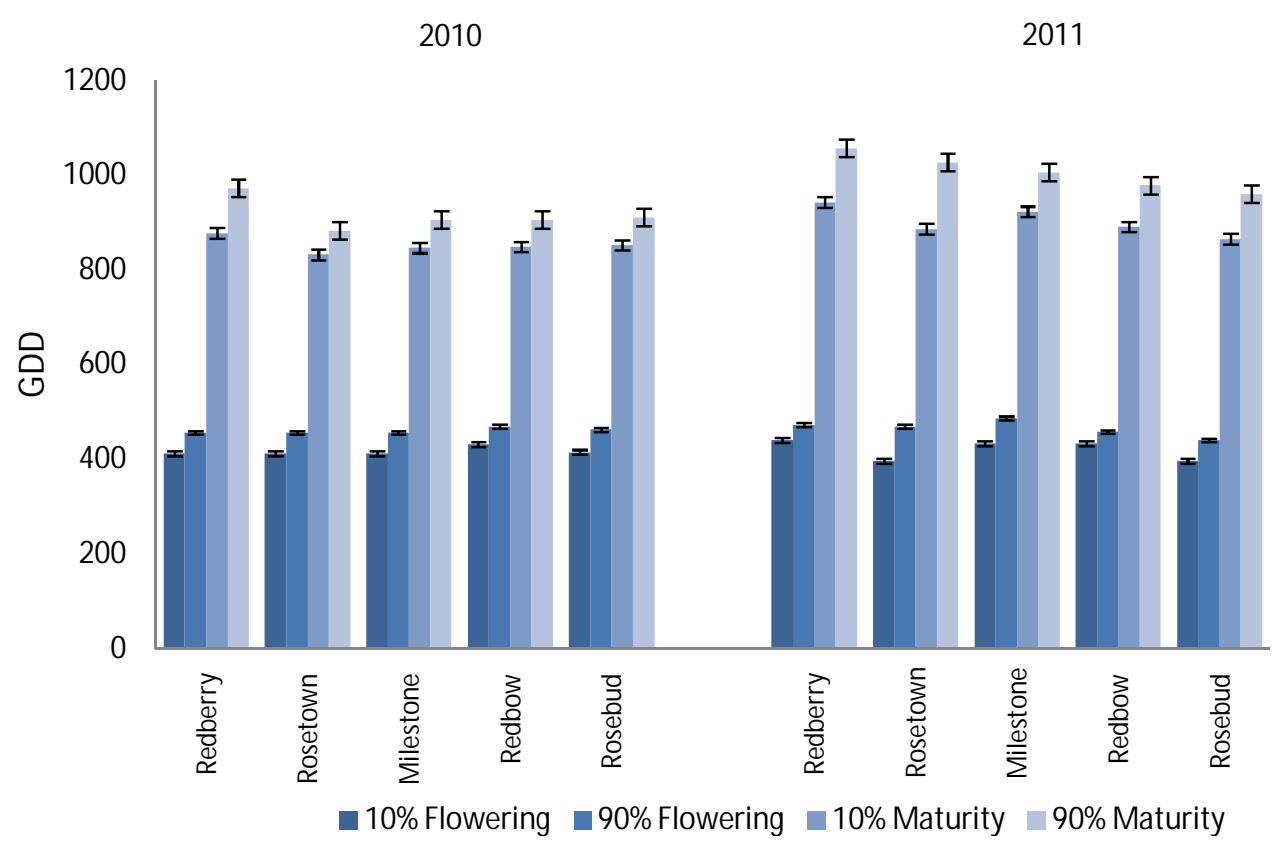

Figure 2. Growing degree days (GDD) accumulated from sowing to $10 \%$ flowering, $90 \%$ flowering, $10 \%$ maturity and 90\% maturity, for five lentil cultivars grown in Helsinki, 2010-2011.

Table 2. Two way analysis of variance for GDD to $10 \%$ flowering, $90 \%$ maturity, seed yield (t/ha), total dry matter (t/ha) and harvest index of 5 lentil cultivars grown in Helsinki in 2010 and 2011.

\begin{tabular}{llccc}
\hline & & \multicolumn{3}{c}{ Mean Square } \\
\cline { 3 - 5 } Source of variation & df & $\begin{array}{c}\text { GDD to 10\% } \\
\text { flowering }\end{array}$ & $\begin{array}{c}\text { GDD to 90\% } \\
\text { Maturity }\end{array}$ & Yield (t/ha) \\
\hline Year & 1 & 121 & $81844^{* * *}$ & 0.096 \\
Cultivar & 4 & $1287 * * *$ & $7914 * * *$ & 0.069 \\
Year x Cultivar & 4 & $910^{* *}$ & $2456^{* * *}$ & 0.052 \\
Residual & 30 & 147 & 292 & 0.096 \\
\hline
\end{tabular}

$* \mathrm{P}<0.05 ; * * \mathrm{P}<0.01 ; * * * \mathrm{P}<0.001$

Lentils grown in Helsinki in both years yielded around 1 to $1.8 \mathrm{t} / \mathrm{ha}$ and a protein content of 263 to $326 \mathrm{~g} / \mathrm{kg}$, and these values are in agreement with those from western Canada (Canadian Grain Commission, 2009). Moreover, there was no significant variation in either yield or total dry matter (TDM) due to cultivar, year or cultivar x year interaction (Table 2). 
The indeterminate growth habit of lentil and the variable environment make it challenging to achieve stable maturity across years. Nevertheless, the yields were fairly stable and our screening trials show that there are several potential cultivars that could be suitable for Finnish agriculture. In particular, cv Rosebud could be a good "pioneer" for the cultivation of lentils in Finland, since it had least variation in 90\% maturity date between 2010 (911 GDD) and 2011 (961 GDD). In addition, climate change predictions indicate that Finland will have a milder climate and a longer growing season in the future, which will facilitate the inclusion of lentils and other legume crops (Maracchi et al 2005, Stoddard et al 2009).

\section{Conclusions}

This study shows that several cultivars of lentil are phenologically well suited to Finnish environmental conditions. It is feasible to grow lentils in southern Finland and they reach maturity in a similar time span as barley. Lentil is tolerant to the warmer temperatures and drier conditions expected from climate change. It can be a valuable break crop for the traditionally grown cereals and farmers have shown interest in growing it.

\section{References}

Canadian Grain Commission. 2009. Quality of western Canadian lentils. www.grainscanada.gc.ca; visited 18.11.2011.

Carlyle, W. 2004. The rise of specialty crops in Saskatchewan, 1981-2001. The Canadian geographer 48 (2):137-151.

Ekroos, J. 2010. Effects of management and landscape structure on biodiversity in boreal agricultural farmland. Academic dissertation. Faculty of Biological and Environmental Sciences. University of Helsinki.

Erskine, W., Muehlbauer, F., Sarker, A., and Sharma, B. Editors. 2009. The lentil. Botany, production and uses. CABI.

FAOSTAT. 2011. FAO statistics division. http://faostat.fao.org. Vienna, Austria: Food and Agriculture Organization of the United Nations; visited 22.11.2011

Maracchi, G., Sirotenko, O., and Bindi, M. 2005. Impacts of present and future climate variability on agriculture and forestry in the temperate regions: Europe. Climatic change 70: 117-135.

Stoddard, F.L., Hovinen, S., Kontturi, M., Lindström, K., and Nykänen, N. 2009. Legumes in Finnish agriculture: History, present status and future prospects. Agricultural and Food Science (18): 191-205.

TIKE. 2010. Maa ja Metsätalousministeriön tietopalvelukeskus. Utilized agricultural area forecast. http://www.mmmtike.fi/www/fi/ visited 21.11.2011 